\title{
Effects of Attitude towards Language Learning and Risk-taking on EFL Student's Proficiency
}

\author{
Elham Dehbozorgi \\ English Department, Faculty of Humanities, Islamic Azad University, Shiraz Branch, Iran \\ E-mail: e.dehbozorgi1985@yahoo.com
}

Received: December 2, 2011

Accepted: January 11, $2012 \quad$ Published: April 1, 2012

doi:10.5539/ijel.v2n2p41

URL: http://dx.doi.org/10.5539/ijel.v2n2p41

\begin{abstract}
This study was an endeavor to investigate effects of attitude towards language learning and risk-taking on EFL students' proficiency. To achieve the objectives of the study, three data gathering instruments were used: Attitude towards Language Learning Scale, Venturesomeness Subscale of Eysenck IVE Questionnaire, and Oxford Quick Placement Test (2005). The participants were 120 female and male college students majoring in English Translation at Marvdasht University. The results showed that the relationship between proficiency level -high, middle, and low - and attitude towards language learning was not significant and the middle proficient participants were higher risk-takers. The results demonstrated differences in risk-taking between high and intermediate levels. Moreover, there was no significant difference between high and low groups and low and middle groups. Correlational analysis revealed a significant positive relationship between attitude towards language learning and risk-taking $(\mathrm{r}=.20, \mathrm{p}<0.05)$. Besides, language proficiency and attitude towards language learning did not have a significant correlation $(\mathrm{r}=.06, \mathrm{p}>0.05)$.
\end{abstract}

Keywords: Attitude towards language learning, Risk-taking, EFL students, Language proficiency

\section{Introduction}

The wide-spread use of English as an international language makes it highly important even in foreign language contexts. In the learning process, affective variables have become an important issue. Considering the significance of this area, Noels, Pelletier, and Vallerand (2000) agree, "In fact, affective variables, such as attitude, orientations, anxiety, and motivation, have been shown to be at least as important as language aptitude for predicting L2 achievement" (p. 35). Oxford (1996) asserts that the affective side of the learners is the most influential aspect in language learning success or failure. Based on the works of some researchers including Dornyei (1990), Ehrman (1996), Gardner (1980), Maclntyre and Charos (1996), seven areas have been defined for affective factors encompassing acculturation, ego, personality, emotion, beliefs, attitude, and motivation. Among these variables, risk-taking as a personality trait and attitude are studied in this research.

Popham (2011) considered the affective domain important because of its influence on learners' future behavior. He asserted,

The reason such affective variables as students' attitudes, interests, and values are important to us is that those variables typically influence future behavior. The reason we want to promote positive attitudes towards learning is because students who have positive attitudes towards learning today will be inclined to pursue learning in the future. The affective status of students lets us see how students are predisposed to behave subsequently. (p. 233)

\subsection{Attitude towards Language Learning}

Language attitude is believed to be the factor that makes differences between underachievement and accomplishment. Spolsky (2000) states that the attitudes towards the language hint at the learners' fears, feelings, or prejudice about the learning of English as a second language. Generally, it is believed that learners' attitudes, skills and strategies dictate whether or not they will be able to absorb the intricacies of language (Oxford, 1990; Nunan, 2000). Ajzen (2005) believes that attitude, like personality trait, is a hypothetical construct that is inaccessible to direct observation and must be inferred from measurable responses. These responses must reflect 
positive or negative evaluations of the attitude object. He states that an attitude is a disposition to respond favorably or unfavorably to the object, person, institution, or event.

According to some researchers, learning a language is closely related to the attitudes towards languages (Starks and Paltridge, 1996). Karahan (2007, p. 84) states that "positive language attitudes let learner have positive orientation towards learning English". As such, attitudes may play a very crucial role in language learning as they can influence students' success or failure in their learning. On the other hand, Gardner (1980) explains that different social contexts may influence the outcomes of studies related to attitudes towards language learning. In his view, the effects of attitude might be much stronger in a context where there is much more of an opportunity for contact between learners and target language speakers than in a foreign language context where learners are not in a close contact with the target cultures and beliefs.

A group of researchers (Latif, Fadzil, Bahroom, Mohammad, San, 2011) conducted a research to determine the relationship between various socio-psychological variables like attitude, motivation, anxiety and instrumental orientation on performance in English as a second language. The results indicated that all of the four variables were significantly correlated with learners' performance in the English course conducted at Open University of Malaysia. Moreover, the regression analysis showed that all the variables except for personal motivation exerted significant impacts on performance with anxiety having a negative impact while attitude and instrumental orientation having positive impacts.

Chalak and Kassaian (2010) investigated motivation and attitude of Iranian undergraduate EFL students towards learning English. The research focused on the motivation orientations of the students and their attitudes towards the target language and its community. A group of 108 students majoring in English Translation in Isfahan, Iran was surveyed using Attitude, Motivation Test Battery (AMTB). The results revealed that these Iranian nonnative speakers of English learned the language for both 'instrumental' and 'integrative' reasons and their attitudes towards the target language community and its members were generally found to be highly positive.

\subsection{Risk-taking}

Brown (2001) states that many instructional contexts around the world do not encourage risk-taking; instead, they encourage correctness, right answers, and withhold "guesses" until one is sure to be correct (p. 63). Risk-taking is directly related to not being afraid to make mistakes. Allowing students to take risks is essential to their leaning. Woodward (2001) asserts, "with a forgiving atmosphere though and plenty of risk-taking, most students can help each other towards the same shared understanding" (p. 112). Moreover, according to McDonough and Shaw (2003: 56),

Success is thought to be based on such factors as checking one's performance in a language, being willing to guess and to 'take risks' with both comprehension and production, seeking out opportunities to practice, developing efficient memorizing strategies, and many others.

Ashouri and Fotovatnia (2010) studied the effects of individual differences on learners' translation beliefs in EFL learning. They examined the learners' beliefs and studied the effects of risk-taking and tolerance on it. The result revealed that participants had positive beliefs about translation but the effect of risk-taking was negative on translation beliefs. As a result, risk-averse learners had positive beliefs about translation, on the other hand; risk-takers were found to have negative beliefs about it.

Ghoorchaei and Kassaian (2009) considered risk-taking in an Iranian context. They investigated whether risk-taking was related to speaking fluency and grammatical accuracy of Iranian EFL students. The results showed that there was not a statistically significant relationship between risk-taking and speaking fluency. However, there was a statistically significant relationship between the grammatical accuracy and risk-taking in speaking.

\section{Research Methodology}

\subsection{Participants}

The participants in the present study were one hundred and twenty EFL learners majoring in English Translation at Marvdasht Azad University, Iran. They were 41 male and 79 female freshmen $(N=20)$, sophomores $(N=20)$, juniors $(N=30)$, and seniors $(N=50)$ between 18 to 30 years old. They were all Iranians and participated in this research willingly. The participants were divided into three levels of proficiency - elementary, intermediate, and advanced. 


\subsection{Instrument}

Three instruments were used to collect the data: a) attitude questionnaire; b) risk-taking questionnaire; c) Oxford Quick Placement Test, Version 2 (2005). The attitude scale was adopted from Hassanpour (1999). It measures the students' attitude towards language learning. The instrument is widely used by different researchers of language learning and psychology. Many had used this scale in their works such as Chilara \& Oller (1978); Pierson, Fu, and Lee (1980); Backon and Finneman (1990); and Spolksky (1969). The questionnaire contains 36 items in a 5-piont Likert scale. The Persian version was used to ensure that the learners had no problem in understanding the items. The questionnaire's reliability was founded to be 0.92 according to Cronbach's alpha formula.

The second instrument for collecting data was the Persian and English versions of Venturesomeness subscale of Eysenck IVE questionnaire. It was used in order to determine the participants' levels of risk-taking. The participants were required to choose among the options that best suited their personality from among the alternatives always, usually, sometimes, rarely, and never. Cronbach's alpha for 16 items of this questionnaire was 0.79 .

The third instrument was Oxford Quick Placement Test (2005). The test consists of 60 items assessing reading, vocabulary and grammar and they are all in multiple-choice format. It includes two parts; part 1 (questions 1-40) is taken by all students and is aimed at those who are intermediate or below and part 2 (question 41-60) is only taken by students who score more than 36 out of 40 in the first part. The task types included reading task and core competence.

\subsection{Data Analysis}

After collecting the data and estimating the scores, the results were analyzed using SPSS (Ver. 16). The participants were divided into three categories of elementary, intermediate, and advanced according to their proficiency test scores. They were sorted based on their proficiency levels in the SPSS software; about the first $27 \%$ were regarded as high proficient, the last $27 \%$ were low proficient and those in between were middle proficient. First, descriptive statistics were calculated. In addition, Pearson Product Moment and Spearman's rho formula was used in order to find the correlation among variables under the study. In addition, a one-way ANOVA was utilized to find out the effects of attitude towards language learning and risk-taking on the performance in the proficiency test. All obtained results and tables were used to draw some conclusion.

\section{Results}

Data analysis revealed the following results. Each participant was given three different scores for their proficiency, attitude, and risk-taking traits. Proficiency test was out of 60 and attitude towards language learning and risk-taking were given values from 1 to 5 and a total score for each of them. The highest possible score for attitude towards language learning was 180 and for risk-taking questionnaire, it was 80 . Those items which were reversed had been re-coded into the same variables. Tables are presented in the Appendix.

Descriptive statistics for the students' performance on the language proficiency test show that the scores ranged from a minimum of 9 to a maximum of 49 , with an average score of 26.88 and a standard deviation of 10.22 . The normal curve in Figure 4.1 and the skewness score show that the curve seemed to be positively skewed (see Table 1).

According to the results which appear in Table 2, the mean score of the advanced learners is 41.63 with a standard deviation of 6.89 , meanwhile their scores range from 30 to 49 . The average score of the intermediate students is 23.91 with a standard deviation of 2.67 and their scores vary from 20 to 30 . Finally, the mean of low level proficiency group is 17.31 with a standard deviation of 2.46 and their scores range from 9 to 20 .

Data related to their attitude towards language learning revels that the mean score for their attitude is 135.91 with a standard deviation of 19.41 and their scores vary from 62 to 170 . The skewness score reveals that the scores on attitude test was negatively skewed. Around $90 \%$ of the participants have attitude scores above 100 . This shows that they have a positive attitude towards language learning. The mean score of the advanced participants is 136.06 with a standard deviation of 21.39 and that of the intermediate group is 138.79 with a standard deviation of 15.84. Low level participants' average score is 130.79 and the standard deviation of their scores is 22.39 . It seems that the intermediate group has the highest level of positive attitude towards language learning.

According to the results of risk-taking questionnaire, the mean score for risk-taking is 46.76 with a standard deviation of 11.10. The scores vary from 22 to 73 . The possible minimum score is 0 and the possible maximum one is 80 . About $48 \%$ receive a risk-taking score more than 45 . The skewness score is also positive and the scores are much more in the left side of the graph. The mean score of the advanced participants is 43.53 with a 
standard deviation of 11.59 and that of the intermediate ones is 50.02 with a standard deviation of 10.94 . Finally, the mean of the low level group is 44.28 and the standard deviation of their scores is 9.50 . Table 4.6 displays statistics for different levels on risk-taking questionnaire.

Obtained data of one-way ANOVA on attitude towards language learning is based on proficiency levels. Results revealed that our learners have positive attitude towards language learning. Most participants receive high scores for their attitude. About $90 \%$ of them have positive attitude towards learning English. In spite of this fact, results of one-way ANOVA analysis show that the relationship between proficiency level -high, middle, and low -and attitude towards language learning is not significant. According to the obtained data, the p-value is 0.17 ( $p>$ 0.05), consequently, there is no relationship between the variables. In this aspect of the research, the null hypothesis can be retained (see table 3 ).

Table 4 highlights statistically significant differences in risk-taking across different groups of proficiency. The $\mathrm{p}$-value in this respect is 0.009 and it is significant $(\mathrm{P}<0.05)$. In order to locate the difference between groups, a post-hoc (Scheffe) test was conducted. The results of this test are reported in Table 4.9.

Results revealed that risk-taking trait is different across proficiency groups. Pos-hoc comparisons reveal that middle proficient participants are higher risk-takers (Mean difference: 6.48 ). The results demonstrate differences in risk-taking between high and intermediate levels. The p-value is 0.02 between high and low proficient groups and it is significant $(\mathrm{p}<0.05)$. There is no significant difference between high and low groups and low and middle groups. In the low level group, the students do not take risks because they have not learnt yet. Likewise, the high level group is not eager to take risks because they have mastered English to some extent (see table 5).

Results highlight a significant positive relationship between attitude towards language learning and risk-taking $(\mathrm{r}=.20, \mathrm{p}<0.05)$ which means increase in risk-taking trait is associated with more positive attitude towards language learning. In addition, language proficiency and risk-taking have a slight negative relationship which is not significant $(\mathrm{r}=-.07, \mathrm{p}>0.05)$. Besides, language proficiency and attitude towards language learning do not have a significant correlation $(\mathrm{r}=.06, \mathrm{p}>0.05)$ (see table 6$)$.

\section{Discussion and Conclusion}

The results revealed that the relationship between Iranian EFL learners' attitude towards language learning and language proficiency was not significant. This result is in contrast with the reports given by Oller, Hudson and Liu (1977) who studied the relations between various measures of attitudes toward self, the native language group, the target language group, reasons for learning English as a second language, reasons for traveling to the U.S. and attained proficiency in ESL. They found that attitude towards self and native language group and attitude towards the target language were positively correlated with attained proficiency in ESL. The different context of these two studies can lead to the contrast. Learners reveal different feelings in EFL and ESL situations. Moreover, the results are different from Gomleksiz (2010) who found some relations between attitude towards language learning and language achievement. Similar to the results of the study, Herbert, Gail and Sik-yum (1980) concluded in their research that English proficiency could not be easily predicted from attitudinal measures, but some attitudinal variables appeared to be better predicator than others. Although the attitudinal variables were not studied separately in the present study, it can be concluded that attitude towards language learning and language proficiency can not always affect each other. Some personal factors such as social views, people's contact with natives and their exposure to the target langue may be important in getting proficient.

Moreover, Results related to risk-taking and attitude towards language learning revealed that these variables correlate positively in the present study but the correlation coefficient was very low. According to Young (1991), learners have to be able to gamble a bit, to be willing to try out impressions about something new and take the risk of being wrong. Positive correlation manifests that learning a language can be an adventure which is more desirable for risk-takers.

Correlation results did not prove to be significant between attitude towards language learning and language proficiency $(\mathrm{p}>0.05)$. The result revealed that Iranian EFL learners have positive attitude but this can not guarantee their proficiency level. It is obvious that attitude towards language learning is a guiding factor for all learners; they can learn eagerly when they have positive attitudes. The effects of this issue on language proficiency can be distracted by some other factors such as their intelligence or thrive for learning. According to Krashen (1985), affective filter can block the input necessary for learning. With regard to attitude, Iranian learners do not have this problem. They do not lack positive attitude, so they can try learning English.

Besides, the correlation between language proficiency and risk taking was not significant. As Beebe (1983) suggested, learners should be moderate risk-takers because high risk-taking can lead to the probability of failure. 
Likewise, Beghetto (2009) found that as students get older they become less likely to take intellectual risks, such as sharing their ideas, when learning. Although it is assumed that risk-taking affects all areas of testing methodologies, high risk-taking may lead to failure and lack of careful attention.

In conclusion, if learners have negative feelings about learning English, teaching will be a difficult task. Consequently, positive attitude is important in entering into the new environment of learning a new language. Teachers can maintain their positive attitude by setting goals for themselves; building in some fun and pleasure through language; and interacting actively.

According to the data, intermediate participants were the first risk-takers. The moderate risk-takers were shown to be the optimal group far as the language proficiency is concerned. The findings are in line with Oxford and Brown (as cited in Oxford, 1999) that "it is more useful for language learners to take moderate but intelligent risks" than taking extreme or no risk at all (p. 63). They also tend to accord with Jonassen and Grabowsky's (1993) statement that "much documentation exist that encourages moderate risk-taking for the empowerment and creative development of the students especially in academic settings" (p. 408). As EFL teachers, we can encourage students to develop an optimal level of risk-taking by integrating appropriate techniques in our teaching and also by providing opportunities so that all students experience improvement and success. As suggested by Brown (2000),very high risk-takers dominate the classroom with wild gambles and need to be tamed by the instructor, but most of the time our concern will be to encourage students to make guesses and to value them as persons for their risk-taking.

\section{References}

Ajzen, I. (2005). Attitude, personality and behavior (2nd ed.). New York: Open University Press.

Allan, D. (2005). Quick placement test. Oxford: Oxford University Press and University of cambridge Local Examinations Syndicate.

Ashouri, A. F., \& Fotovatnia, Z. (2010). The effects of individual diffrences on learners' translation belief in EFL learning. English Language Teaching , 3(4), 288-236.

Bacon, S. M., \& Finneman, M. D. (1990). A study of attitude, motivation, and strategies of university students and their disposition. Modern Language Journal, 74 (4), 459-473. http://dx.doi.org/10.1111/j.1540-4781.1990.tb05338.x

Beebe, L. M. (1983). Risk-taking and language learner, edited by H. W. Selinger, \& M. H. Long. ROwley, MA: Newbury House.

Beghetto, R. A. (2009). Correlates of intellectual risk taking in elementry school science. Journal of Research in ScienceTeaching, 46(2), 210-223. http://dx.doi.org/10.1002/tea.20270

Brown, H. D. (2001). Teaching by principles: An interactive approach to language Pedagogy. New York: Addition Wesley: Longman, Inc.

Chalak, A., \& Kassaian, Z. (2010). Motivation and attitudes of Iranian undergraduate EFL students towards learning English. GEMA Online Journal of Language Studies, 10(2), 37-56.

Chihara, T., \& Oller, J. W. (1978). Attitudes and attained proficiency in EFL: A sociolinguistic study of adult Japanese speakers. language Learning, 29(1), 55-68.

Dornyei, Z. (1990). Conceptualizing motivation in foreign-language learning. Language Learning , 40(1), 45-75. http://dx.doi.org/10.1111/j.1467-1770.1990.tb00954.x

Ehrman, M. (1996). An Exploration of Adult language Learner Motivation, Self- Efficacy, and Anxiety. In R. L. Oxford (Ed.), Learning motivations: pathways to the new center (pp. 81-103). Honolulu: University of Hawaii: Second language Teaching and Curriculum Center.

Gardner, R. (1980). On the validity of affective variables in second language acquisition: conceptual, contextual and statistical consideration. Language Learning, 30, 255-270. http://dx.doi.org/10.1111/j.1467-1770.1980.tb00318.x

Ghoorchaei, B., \& Kassaian, Z. (2009). The relationship between risk-taking, fluency and accuracy in English speech of Iranian EFL students. Iranian EFL Journal, 3, 111-136.

Gomleksiz, M. N. (2010). An evaluation of students' attitudes toward English language learning in terms of several variables. Procedia Social and Behavioral Sciences, 9, 913-918. http://dx.doi.org/10.1016/j.sbspro.2010.12.258 
Hassanpour, M. (1999). Science students' use of learning studies and its relation to motivation, attitude and gender. Unpublished M. A. thesis, Shiraz Islamic Azad University, Shiraz, Iran.

Herbert, D. P., Gail, S. F., \& Sik-yum, L. (1980). An analysis of the relationship between language attitudes and English attainment of secondary students in Hong Kong. Language Learning, 30(2), 289-305. http://dx.doi.org/10.1111/j.1467-1770.1980.tb00320.x

Jonassen, D. H., \& Grabowski, B. L. (1993). Handbook of individual differences, learning, and instruction. Hillsdale, New Jersey: Lawrence Erlbaum Associates, Inc.

Karahan, F. (2007). Language attitudes of Turkish students towards the English language and its use in Turkish context. Journal of Arts and Sciences, 7, 73-87.

Krashen, S. (1985). Language acquisition and language education. California: Alemany Press.

Latif, L. A., Fadzil, M., Bahroom, R., Mohammad, W., \& San, N. M. (2011). The role of motivation, attitude, anxiety and instrumental orientaion in influencing learners' performance in English as a second language in OUM. Global Confrence on Learning and Technology. Melbourne, Australia: Global learn Asia Pasific. Retrieved from http://eprints.oum.edu.my/56

Maclntyre, P. D., \& Charos, C. (1996). Personality, attitudes, and affect as predicators of second language communication. Journal of Language and Social Psychology, 15(1), 3-26. http://dx.doi.org/10.1177/0261927X960151001

McDonogh, J., \& Shaw, C. (2003). Materials and methods in ELT (2nd ed.). Oxford: Blackwell Publishing.

Noels, K. A., Pelletier, L. G., \& Vallerand, R. J. (2000). Why are you learning a second language? Motivational orietation and self-determination theory. Language Learning, 50, 57-85. http://dx.doi.org/10.1111/0023-8333.00111

Nunan, D. (2000). Language Teaching Methodology (2nd Impression). Harlow: Pearson Education Ltd.

Oller, J. W., Hudson, J. A., \& Lui, P. F. (1977). Attitudes and attained proficiency in ESL: A sociolinguistic study of native speakers of Chinese in the United States. Language Learing, 27(1), 1-23. http://dx.doi.org/10.1111/j.1467-1770.1977.tb00289.x

Oxford, R. (1990). Language learning strategies. Boston: Heinle and Heinle Publishers.

Oxford, R. (1996). Language learning strategies around the world: Cross-cultural perspectives. Hawaii, Manoa: Second Language Teaching \& Curriculum Center.

Oxford, R. L. (1999). Anxiety and the language learner: new insights. In J. Arnold (Ed.), Affect in language learning (pp. 58-67). Cambridge: Cambridge University Press.

Pierson, H. D., Fu, G. S., \& Lee, S. (1980). An analysis of the relationship between language attitudes and English attainment of secondary school students in Hong Kong. Language Learning, 30, 289-316. http://dx.doi.org/10.1111/j.1467-1770.1980.tb00320.x

Popham, W. J. (2011). Classroom assessment: What teachers need to know. Boston, MA: Pearson.

Spolsky, B. (1969). Attitudinal aspects of second language learning. Language Learning, 19, 271-281. http://dx.doi.org/10.1111/j.1467-1770.1969.tb00468.x

Spolsky, B. (2000). Language motivation revisited: Anniversary article. Applied Linguistics, 20(2), 157-169. http://dx.doi.org/10.1093/applin/21.2.157

Starks, D., \& Paltridge, B. (1996). A note on using sociolinguistic methods to study nonnative attitudes towards English. World Englishes, 15(2), 217-224. http://dx.doi.org/10.1111/j.1467-971X.1996.tb00107.x

Woodward, T. (2001). Planning lessons and courses. Cambridge: Cambridge University Press. http://dx.doi.org/10.1017/CBO9780511732973

Young, D. R. (1991). Risk-taking in learning, K-3. NEA early childhood education series. Washington D. C.: National Education Association. 
Table 1. Descriptive statistics for the language proficeincy test

\begin{tabular}{|l|c|c|c|c|c|c|c|}
\hline & N & Minimum & Maximum & Mean & $\begin{array}{r}\text { Std. } \\
\text { Deviation }\end{array}$ & \multicolumn{2}{c|}{ Skewness } \\
& Statistic & Statistic & Statistic & Statistic & Statistic & Statistic & Std. Error \\
\hline $\begin{array}{l}\text { prof.test } \\
\text { Valid N }\end{array}$ & 120 & 9 & 49 & 26.88 & 10.222 & .977 & .221 \\
\hline
\end{tabular}

Table 2. Descriptive statistics on proficiency scores in different groups

\begin{tabular}{|l|c|c|c|c|c|}
\hline Level & N & Minimum & Maximum & Mean & $\begin{array}{c}\text { Std. } \\
\text { Deviation }\end{array}$ \\
\hline Advanced & 32 & 30 & 49 & 41.63 & 6.890 \\
Intermediate & 56 & 20 & 30 & 23.91 & 2.672 \\
Low & 32 & 9 & 20 & 17.31 & 2.468 \\
\hline
\end{tabular}

Table 3. One-way ANOVA results on attitude towards language learning and language level

\begin{tabular}{|l|c|c|c|c|c|}
\hline & $\begin{array}{c}\text { Sum of } \\
\text { Squares }\end{array}$ & df & $\begin{array}{c}\text { Mean } \\
\text { Square }\end{array}$ & F & Sig. \\
\hline Between & 1326.219 & 2 & 663.110 & 1.782 & .173 \\
Groups & 43535.772 & 117 & 372.101 & & \\
Within Groups & 44861.992 & 119 & & & \\
\hline
\end{tabular}

Table 4. One-way ANOVA results on language proficiency levels and risk-taking

\begin{tabular}{|l|c|c|r|r|r|}
\hline & \multicolumn{1}{|c|}{$\begin{array}{c}\text { Sum of } \\
\text { Squares }\end{array}$} & df & $\begin{array}{c}\text { Mean } \\
\text { Square }\end{array}$ & F & Sig. \\
\hline Between & 1124.572 & 2 & 562.286 & 4.852 & .009 \\
Groups & 13559.420 & 117 & 115.892 & & \\
Within Groups & 14683.992 & 119 & & & \\
Total & & & & & \\
\hline
\end{tabular}


Table 5. Multiple comparisons of language proficiency and risk-taking

\begin{tabular}{|c|c|c|c|c|c|c|}
\hline \multirow{2}{*}{ (I) level } & \multirow{2}{*}{ (J) level } & \multirow{2}{*}{ Mean Difference (I-J) } & \multirow{2}{*}{ Std. Error } & \multirow{2}{*}{ Sig. } & \multicolumn{2}{|c|}{$95 \%$ Confidence Interval } \\
\hline & & & & & Lower Bound & Upper Bound \\
\hline \multirow[t]{2}{*}{ high proficient } & middle proficient & $-6.487 *$ & 2.386 & .028 & -12.40 & -.57 \\
\hline & low proficient & -.750 & 2.691 & .962 & -7.42 & 5.92 \\
\hline \multirow{2}{*}{\multicolumn{2}{|c|}{$\begin{array}{l}\text { middle proficient high proficient } \\
\text { low proficient }\end{array}$}} & 6.487 & 2.386 & .028 & .57 & 12.40 \\
\hline & & 5.737 & 2.386 & .059 & -.18 & 11.65 \\
\hline \multirow[t]{2}{*}{ low proficient } & high proficient & .750 & 2.691 & .962 & -5.92 & 7.42 \\
\hline & middle proficient & -5.737 & 2.386 & .059 & -11.65 & .18 \\
\hline
\end{tabular}

Table 6. Pearson correlation between variables

\begin{tabular}{|c|c|c|c|}
\hline & & Risk & prof.test \\
\hline \multirow[t]{3}{*}{ Attitude } & $\begin{array}{l}\text { Pearson } \\
\text { Correlation }\end{array}$ & $.208(*)$ & .065 \\
\hline & Sig. (2-tailed) & .022 & .482 \\
\hline & $\mathrm{N}$ & 120 & 120 \\
\hline \multirow[t]{4}{*}{ prof.test } & Pearson & \multirow{2}{*}{-.076} & \\
\hline & Correlation & & \\
\hline & Sig. (2-tailed) & .410 & \\
\hline & $\mathrm{N}$ & 120 & \\
\hline
\end{tabular}

* Correlation is significant at the 0.05 level (2-tailed). 